\title{
Performance Assessment of Wastewater Treatment Plants (WWTPs ) and Application of Electrocoagulation Process to Improve Their Operation
}

\author{
Sid Ahmed Tertouche ${ }^{1}$, Sohbi Bellebia ${ }^{1}$, Zohra Bengharez ${ }^{1 *}$, \\ Zohra Zian', Salah Jellali² \\ ${ }^{1}$ Laboratory of Advanced Materials and Physicochemistry for Environment and Health. \\ Djillali Liabes University of Sidi Bel Abbes, Algeria \\ ${ }^{2}$ PEIE Research Chair for the Development of Industrial Estates and Free Zones, Center for Environmental \\ Studies and Research, Sultan Qaboos University, Al-Khoud 123, Oman
}

Received: 25 December 2020

Accepted: 8 March 2021

\begin{abstract}
The present study aimed to assess the efficiency of two wastewater treatment plants (WWTPs) operating with different biological processes and to investigate the electrocoagulation process as alternative to improve their operation.

Results revealed the consistent efficiency of urban WWTP that uses activated sludge process, the station operated with removal efficiencies higher than $91 \%$ for biological oxygen demand (BOD), chemical oxygen demand (COD) and total suspended solids (TSS) and produced high quality effluent whereas the efficiency of WWTP of an industrial complex using trickling filter process was in the monitored period very small and did not meet the minimum acceptable treatment efficiency of discharged wastewater. The treatment assays with electrocoagulation process using aluminium electrodes exhibited high COD removal particularly for plant of industrial site, the optimal operating conditions for the maximum COD removal are found to be the initial $\mathrm{pH}$ of 3 , current density of $29.79 \mathrm{~mA} / \mathrm{cm}^{2}$, electrolysis time of $5 \mathrm{~min}$ and charge loading of $26.11 \mathrm{~F} / \mathrm{m}^{3}$. Under these conditions, the removal efficiency of COD is found to be $79 \%$. Consequently, electrocoagulation process can be recommended to improve the performance of WWTPs. Nonetheless, the implementation of EC into industrial or municipal systems should be investigated more.
\end{abstract}

Keywords: wastewater treatment plant, biological process, electrocoagulation, efficiency, optimization

*e-mail: dzbengharez@yahoo.fr 


\section{Introduction}

The rapid population growth in combination with the massive urbanization and the development of industrial and agricultural activities worldwide, have generated a significant wastewaters production that usually do not meet the environmental regulations for being discharged directly into the receiving water [1]. The majority of produced wastewater, estimated at over $80 \%$, is released to the environment without adequate treatment especially in developing countries due to lacking infrastructure, technical and institutional capacity and financing [2]. Untreated or incompletely treated wastewater poses a serious threat to the environment and human health [3].

The annual discharged wastewater amount in overall Algeria is currently estimated to about 900 million $\mathrm{m}^{3}$ and will probably exceed 1.5 billion $\mathrm{m}^{3}$ by 2021 [4]. Facing the high potential of the produced wastewaters as well as their menaces to existing surface and underground water resources, the realization and renovation of wastewaters purification facilities has been pointed out as a crucial emergency by the Ministry of Water Resources and Environment. In 2004, an ambitious program was launched for the construction of 134 wastewaters treatment plants (WWTPs) with a total capacity estimated to about 12 million PE (Population Equivalent). Consequently, the number of operating WWTPs has continued to grow, from 12 in 1999 to 112 in 2009, 164 in 2014 and 272 units in the next ten years [5]. If today wastewaters are treated to preserve water quality of rivers and receiving lakes and to protect the Mediterranean Sea against pollution (Barcelona Convention 26 January 1980), much of the purified volume is destined for irrigation. In fact, treated wastewater is considered as an essential alternative for the conventional water resources especially for countries characterized by an arid or semi-arid climate.

The most used purification processes of urban, industrial and agricultural wastewaters in Algeria consist of: i) natural lagooning where the removal of the organic pollution load is done naturally in stabilization basins, ii) the activated sludge process where the removal of organic charge takes place mainly in the aeration basins and iii) purification through trickling filters.

Purification by natural lagooning has attracted particular interest among those responsible for sanitation, this interest is justified by the advantages offered by this technique, such as low investment and maintenance costs, adaptation to load fluctuations and the high capacity to remove bacterial pollution compared to activated sludge [6,7]. Concerning the activated sludge treatment process, it has been shown that its efficiency depends mainly on the pollution load to be treated and the age of the sludge [8]. According to literature data [9], the activated sludge process has many drawbacks, such as low efficiency to separate solids from water, sensitivity to hydraulic overloads, high energy consumption and low mixing of suspended solids TSS.

The treatment of sewage with trickling filters is considered to be a limited technique despite the advantages it offers, namely simplicity of process, moderate energy consumption, thickened sludge by settler-digester and lower sensitivity to load variations [10]. The major limitations of this process are its sensitivity to clogging, especially with traditional supports, high capital costs in comparison with activated sludge, limited nitrogen abatement and the need for effective pretreatment.

Nowadays, a large amount of research has been conducted in the application of electrochemical methods as alternative processes for elimination of contaminants in effluents [11]. Electrocoagulation (EC) is an electrochemical technique whereby anodes (mostly iron and aluminum) corrode to release active coagulants and gas bubbles [12]. The mains reactions that occurs in EC Process are represented by equations 1, 2 and 3 . The generated metallic ions, $\mathrm{Al}^{3+}{ }_{\text {aq }}, \mathrm{Fe}^{3+}$ aq or $\mathrm{Fe}^{2+}$ aq will react with hydroxyl ions and produce metal hydroxide and polyhydroxide ions $\mathrm{M}(\mathrm{OH}) \mathrm{n}$ solubles or insoluble which favor the formation of flocks. These compounds have a strong affinity with dispersed/dissolved molecules as well as any dissolved ions to cause coagulation/ adsorption [13, 14].

At the anode:

$$
\begin{gathered}
M(s) \rightarrow M^{\mathrm{n}+}(a q)+\mathrm{ne}^{-} \\
2 \mathrm{H}_{2} \mathrm{O} \rightarrow 4 \mathrm{H}^{+}(a q)+\mathrm{O}_{2}(g)+4 e^{-}
\end{gathered}
$$

At the cathode:

$$
n \mathrm{H}_{2} \mathrm{O}+n e^{-} \rightarrow(n / 2) \mathrm{H}_{2}(g)+n \mathrm{OH}^{-}(a q)
$$

EC is considered to be a simple, reliable, costeffective and effective technology for color, heavy metals and COD removal from wastewaters with relatively low energy consumption [15]. Moreover this process is characterized by reduced sludge production, no requirement for chemical use and ease of operation [16].

If biological treatment remains the fondamental process in WWTPs, physical, chemical or electrochemical treatment can be used as pre-treatment, post-treatment, or both in order to enhance the physicochemical quality of effluents. The main combinations that have been successfully applied in the treatment of wastewater were reported by Bazrafshan et al. [17] and Klauson et al. [18] who achieved over 90\% COD and $\mathrm{BOD}_{5}$ removal.

In this sense, the main objectives of this study are: 1) To evaluate the current treatment performance of two important WWTPs located in Sidi Bel Abbes city (North-West Algeria) using biological treatment 
methods 2) To test the electrocoagulation process (EC) and its efficiency in removing the chemical oxygen demand (COD) from wastewaters of these tow WWTPs as alternatives to improve their operation 3) to consider the possibility of integrating the EC into the treatment plant by optimizing the most important parameters influencing the process.

\section{Materials and Methods}

\section{Description of WWTPs}

The WWTPs selected for this study are located in Sidi Bel Abbes city, North-West Algeria and operate with different processing techniques.

WWTP1 (Site 1): of an industrial complex based on trickling filter process, the plant has a design capacity of $800 \mathrm{~m}^{3} /$ day and is recognized as a small-scale wastewater treatment facility. Fig. 1 shows a general diagram of the different processing steps applied to the WWTP1.

WWTP 2 (Site 2): Plant destined to treat produced urban wastewaters of Sidi Bel Abbes city and its surroundings by activated sludge technology, this WWTP was dimensioned to treat a total volume corresponding to $220000 \mathrm{PE}$ but it is currently receiving about 6000 to $7000 \mathrm{~m}^{3}$ daily instead of $28000 \mathrm{~m}^{3} /$ day. A descriptive diagram of the used purification process is shown in Fig. 2.

\section{Parameters and Analytical Methods}

Sampling was carried out at the inlet of the selected plants (raw wastewaters: influent concentrations) and at the outlet (treated wastewaters: effluent concentrations). After collection, the samples were immediately transferred into a cooling box and transported to the laboratory for analysis. Physico-chemical analyses were carried out at a frequency of 4 times per year in accordance with international standard methods [19].

The $\mathrm{pH}$, temperature and conductivity measurements were carried out on-site using a multi-parameter probe $\mathrm{HACH}$ - Sens Ion 156. The analyses performed at the laboratory concerned the following parameters: Chemical Oxygen Demand (COD), five-days Biological Oxygen Demand $\left(\mathrm{BOD}_{5}\right)$ and Total Suspended Solids (TSS) according to standard experimental protocols for examination of water and wastewater $[19,20]$ and Nitrates $\left(\mathrm{NO}_{3}^{-}\right)$by UV-Visible spectrophotometry (SHIMADZU UV-2401 PC).

All data were statistically analyzed and expressed in term of mean \pm standard deviation by using STATISTICA Version 7 software.

\section{Description of the EC Process}

The electrocoagulation system used in the experimental studies is shown in Fig. 3.

For reading of current and voltage values, a multimeter and a voltmeter were connected in monopolar mode in parallel with a direct current

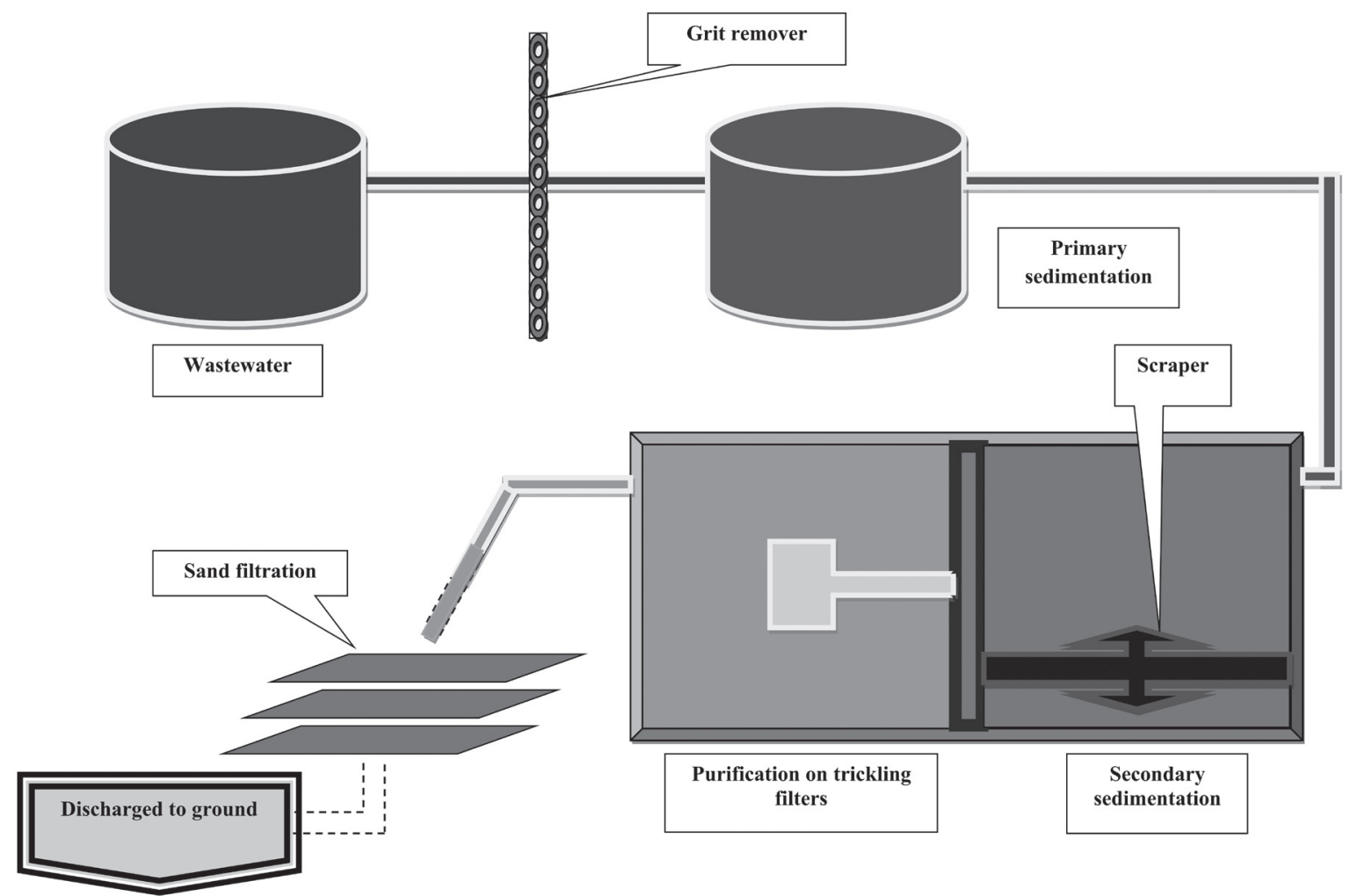

Fig. 1. General diagram of different processing steps applied to the WWTP1. 


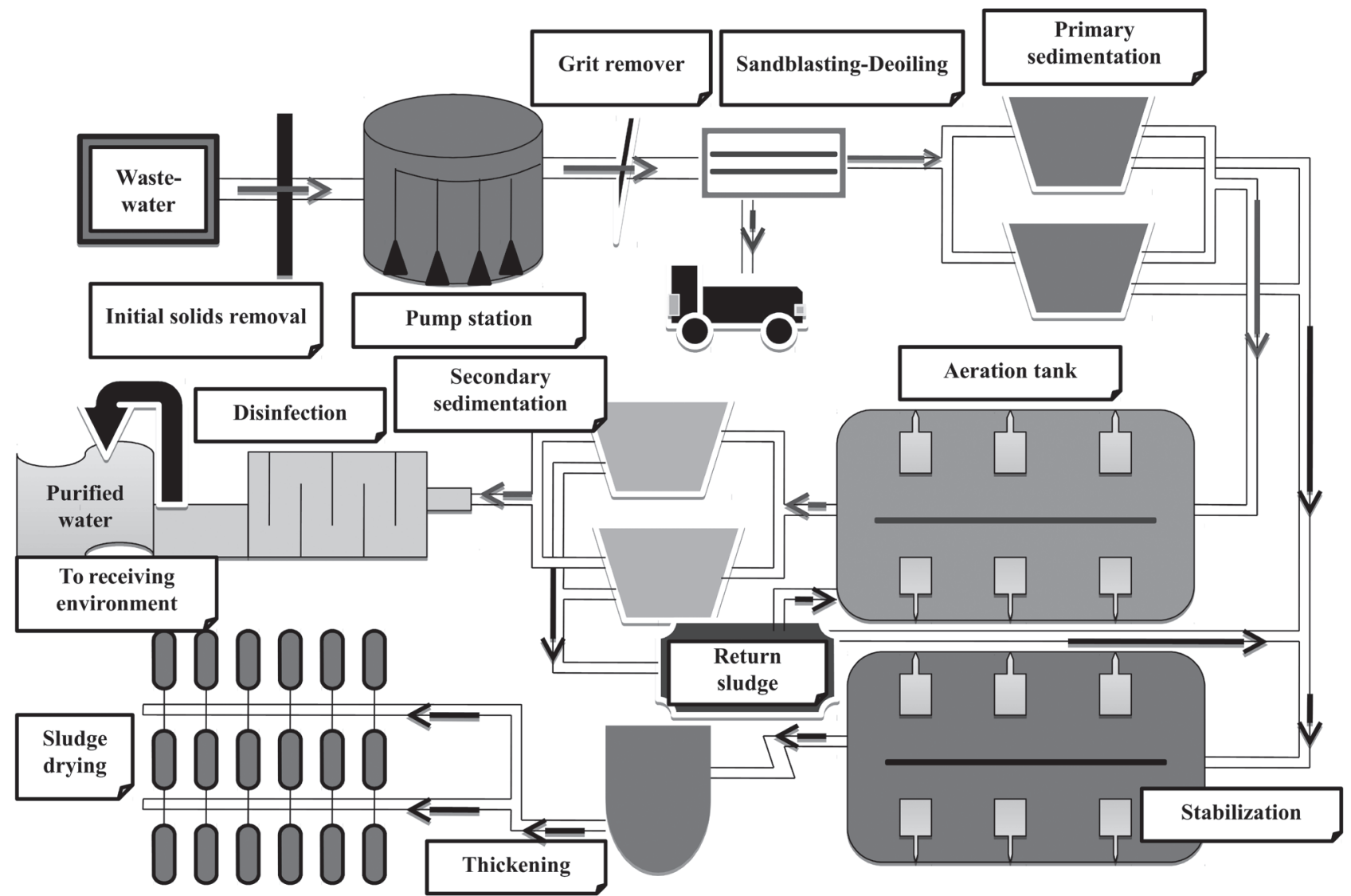

Fig. 2. General diagram of different processing steps applied to the WWTP 2.

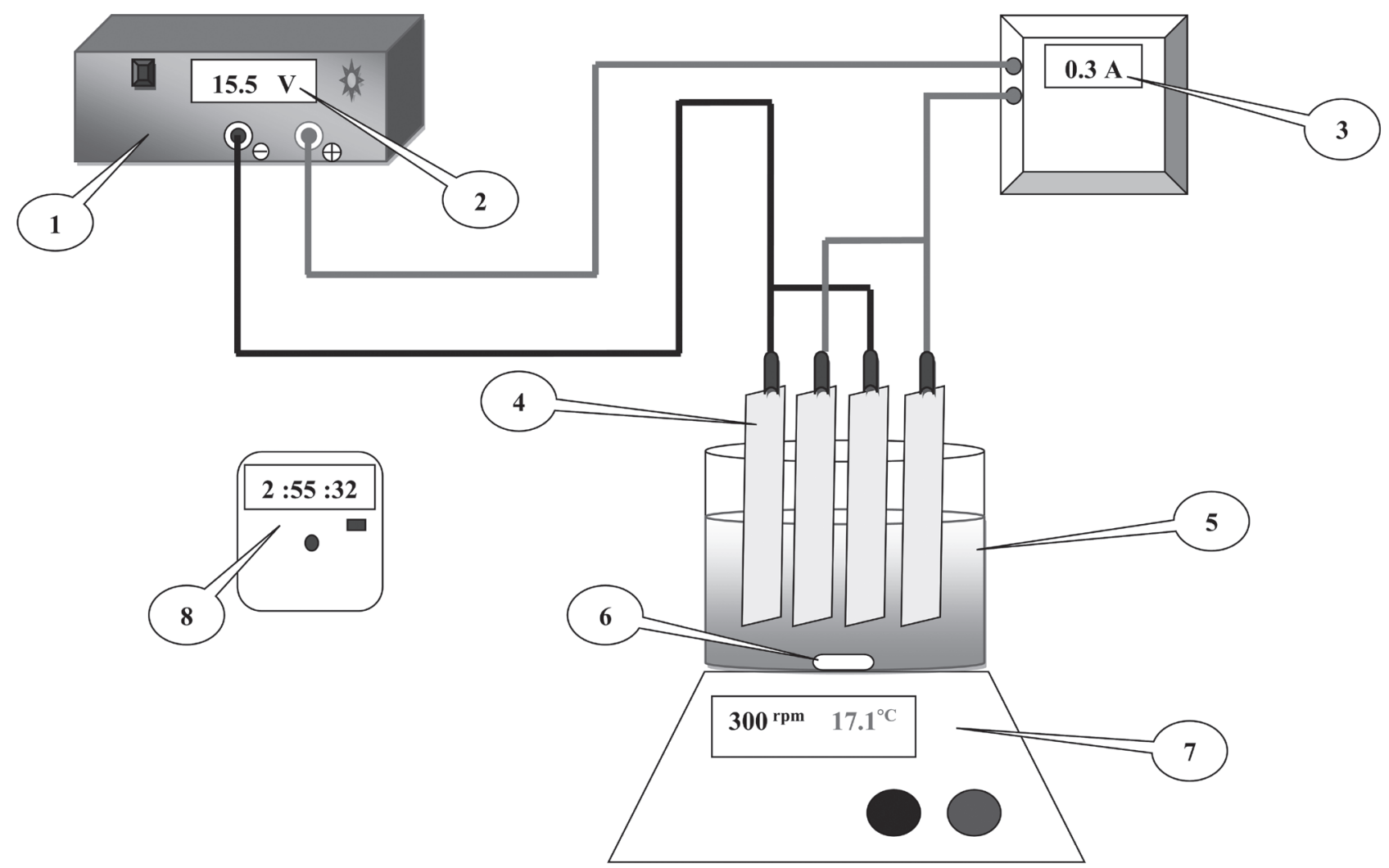

Fig. 3. Schematic diagram of the electrocoagulation process: (1) DC power supply, (2) voltmeter, (3) multimeter, (4) aluminum electrodes, (5) electrocoagulation cell + wastewater, (6) magnetic stirring bar, (7) magnetic stirring hot plate controller, (8) stopwatch. 
power supply (Leybold Didactic GMBH, Germany). Experiments were carried out in plexiglas cell having dimensions of $(10 \mathrm{~cm} \times 7 \mathrm{~cm} \times 6 \mathrm{~cm})$, equipped with four Aluminum electrodes $(99.40 \%$ purity). Cathode and anode with dimensions of $(10 \mathrm{~cm} \times 5 \mathrm{~cm} \times 0.1 \mathrm{~cm})$ and a total effective area of $70.5 \mathrm{~cm}^{2}$ were used. The net spacing between each electrode was $1.3 \mathrm{~cm}$ with $4.7 \mathrm{~cm}$ depth immersed into wastewater. A volume of $250 \mathrm{~mL}$ of wastewater was introduced into the cell of EC and maintained under constant stirring of $300 \mathrm{rpm}$ and at ambient temperature using a digital magnetic hotplate stirrer (MS-H-Pro+ Germany). At the beginning of each experiment, the current density was adjusted to a desired value. Sulfuric acid $\left(\mathrm{H}_{2} \mathrm{SO}_{4}\right)$ or sodium hydroxide $(\mathrm{NaOH})$ (Merck, Germany) were employed to adjust $\mathrm{pH}$ of solutions. The samples were taken at every 5 min interval from the cell and the solution was filtered for COD analyses. The COD removal efficiency, the charge loading and the electrical energy consumed during process were determined from equations 4,5 and 6 respectively.

COD removal efficiency $\%=\frac{(\mathrm{COD})_{0}-(\mathrm{COD})_{\mathrm{R}}}{(\mathrm{COD})_{0}} * 100$

$$
\mathrm{Q}\left(\mathrm{F} / \mathrm{m}^{3}\right)=\frac{\mathrm{I} * \mathrm{t}}{96500 * \mathrm{~V}}
$$

$$
\operatorname{EEC}\left(\mathrm{kwh} / \mathrm{m}^{3}\right)=\frac{\text { U.I.t }}{\mathrm{V}}
$$

...where $(\mathrm{COD})_{0}$ and $(\mathrm{COD})_{\mathrm{R}}$ are the initial and equilibrium $\mathrm{COD}$ concentrations $\left(\mathrm{mg} \quad \mathrm{O}_{2} / \mathrm{L}\right)$, respectively, U: used voltage (Volt), I: current (A), t: time (h) and V: volume (L)

To achieve the maximum removal efficiency using electrocoagulation process, effects of important operational parameters on EC process namely: current density, charge loading and initial $\mathrm{pH}$ were investigated and optimized.

\section{Results and Discussion}

Detailed results of the physicochemical analyses of the raw and treated wastewaters of the two WWTPs (S1 ans S2) as well as the corresponding removal percentage are summarized in Tables 1 and 2.

Based on the obtained results, excepting COD and $\mathrm{BOD}_{5}$ concentrations of effluent wastewater from WWTP 1, all assayed parameters were found to be below the maximum limits specified by both Algerian and World Health Organization guidelines [21, 22] for effluents intended for discharge into any receiving body (public sewer, land for irrigation, inland surface water and marine coastal areas).

Effluent characteristics from WWTP 2 (Table 2) clearly demonstrate its high quality and suitability for unrestricted irrigation, the average values obtained in the effluent for all analyzed parameters were consistent with Algerian standards for wastewaters quality for irrigation [21] and with the limits recommended by Food and Agriculture Organization of the United Nations [23]. On the contrary, for WWTP 1 the chemical oxygen demand (COD) concentration in treated effluent was evaluated at $124.6 \pm 35.02 \mathrm{mg} \mathrm{O}_{2} / \mathrm{L}$, well above the discharging limit value fixed at $90 \mathrm{mg} \mathrm{O}_{2} / \mathrm{L}$ and the mean $\mathrm{BOD}_{5}$ value observed was $41.25 \pm 7.889 \mathrm{mg} \mathrm{O}_{2} / \mathrm{L}$ whereas the FAO standard requires a $\mathrm{BOD}_{5}$ less than

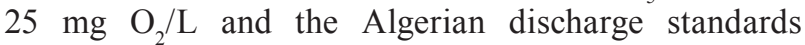
recommend a maximum value of $30 \mathrm{mg} \mathrm{O}_{2} / \mathrm{L}$.

The $\mathrm{COD} / \mathrm{BOD}_{5}$ ratio characterizes the biodegradability of wastewaters entering the WWTP, low ratio values $(<2.5)$ indicate the presence of relatively high proportion of biodegradable matters. Therefore, the use of biological methods for the wastewaters treatment is recommended. Conversely, an important value of this

\begin{tabular}{|c|c|c|c|c|c|c|c|c|}
\hline \multirow{2}{*}{ Parameter } & \multicolumn{3}{|c|}{ Raw wastewater } & \multicolumn{3}{|c|}{ Purified wastewater } & \multirow{2}{*}{$\begin{array}{c}\text { Removal percentage } \\
(\%)\end{array}$} & \multirow[t]{2}{*}{ Norms* } \\
\hline & Min & Max & Mean \pm SD & Min & Max & Mean \pm SD & & \\
\hline $\mathrm{T}\left({ }^{\circ} \mathrm{C}\right)$ & 17.4 & 18.3 & $17.85 \pm 0.420$ & 15.8 & 17.5 & $16.9 \pm 0.804$ & - & - \\
\hline $\mathrm{pH}$ & 7.2 & 7.4 & $7.3 \pm 0.081$ & 7.8 & 8.7 & $8.275 \pm 0.403$ & - & $6.5 \leq \mathrm{pH} \leq 8.5$ \\
\hline Cond $(\mu \mathrm{S} / \mathrm{cm})$ & 2300 & 2900 & $2575 \pm 250$ & 1700 & 2400 & $2010 \pm 308.3$ & $22.24 \pm 4.697$ & 3000 \\
\hline $\mathrm{NO}_{3}^{-}(\mathrm{mg} / \mathrm{L})$ & 0.22 & 0.27 & $0.24 \pm 0.021$ & 0.03 & 0.07 & $0.05 \pm 0.018$ & $76.96 \pm 4.226$ & 30 \\
\hline TSS (mg/L) & 6.8 & 57 & $24.92 \pm 22.33$ & 4.8 & 22 & $12.42 \pm 7.238$ & $39.86 \pm 15.76$ & 30 \\
\hline $\mathrm{COD}(\mathrm{mg} / \mathrm{L})$ & 98.3 & 231.9 & $159.0 \pm 60.07$ & 85.6 & 161.6 & $124.6 \pm 35.02$ & $19.46 \pm 7.926$ & 90 \\
\hline $\mathrm{BOD}_{5}(\mathrm{mg} / \mathrm{L})$ & 40 & 70 & $58 \pm 13.14$ & 30 & 48 & $41.25 \pm 7.889$ & $28.37 \pm 3.194$ & 30 \\
\hline $\mathrm{COD} / \mathrm{BOD}_{5}$ & 1.72 & 5.79 & $3 \pm 1.89$ & - & - & - & - & - \\
\hline
\end{tabular}

Table 1. Analyzed physicochemical parameters of raw and purified wastewater of the WWTP1(S1) and the removal percentage..

* Algerian Wastewater Discharge Standards (JORA 2012) 
Table 2. Analyzed physicochemical parameters of raw and purified wastewater of the WWTP2 (S2) and the removal percentage.

\begin{tabular}{|c|c|c|c|c|c|c|c|c|}
\hline \multirow{2}{*}{ Parameter } & \multicolumn{3}{|c|}{ Raw wastewater } & \multicolumn{3}{|c|}{ Purified wastewater } & \multirow{2}{*}{$\begin{array}{c}\text { Removal percentage } \\
(\%)\end{array}$} & \multirow[t]{2}{*}{ Norms* } \\
\hline & Min & Max & Mean \pm SD & Min & Max & Mean \pm SD & & \\
\hline $\mathrm{T}\left({ }^{\circ} \mathrm{C}\right)$ & 15.3 & 26.1 & $20.27 \pm 4.636$ & 14.5 & 25.9 & $19.75 \pm 4.840$ & & \\
\hline $\mathrm{pH}$ & 8.1 & 8.3 & $8.2 \pm 0.081$ & 8.1 & 8.4 & $8.275 \pm 0.125$ & & $6.5 \leq \mathrm{pH} \leq 8.5$ \\
\hline Cond $(\mu \mathrm{S} / \mathrm{cm})$ & 1701 & 1865 & $1802 \pm 70.92$ & 1074 & 1147 & $1117 \pm 34.13$ & $37.99 \pm 1.837$ & 3000 \\
\hline $\mathrm{NO}_{3}^{-}(\mathrm{mg} / \mathrm{L})$ & 0.08 & 0.52 & $0.282 \pm 0.186$ & 0.03 & 0.09 & $0.055 \pm 0.03$ & $75.62 \pm 13.26$ & 30 \\
\hline $\mathrm{TSS}(\mathrm{mg} / \mathrm{L})$ & 595 & 728 & $659.2 \pm 55.54$ & 11 & 14 & $13 \pm 1.414$ & $98 \pm 0.363$ & 30 \\
\hline $\mathrm{COD}(\mathrm{mg} / \mathrm{L})$ & 554 & 744 & $689.7 \pm 90.73$ & 53 & 62 & $56.75 \pm 4.112$ & $91.68 \pm 1.054$ & 90 \\
\hline $\mathrm{BOD}_{5}(\mathrm{mg} / \mathrm{L})$ & 288 & 360 & $331.7 \pm 33.23$ & 26 & 30 & $28.25 \pm 1.707$ & $91.40 \pm 1.098$ & 30 \\
\hline $\mathrm{COD} / \mathrm{BOD}_{5}$ & 1.92 & 2.30 & $2.08 \pm 0.16$ & - & - & - & - & - \\
\hline
\end{tabular}

*Algerian Wastewater Discharge Standards (JORA 2012)

ratio points out low wastewater biodegradability $[24$, 25].

The average value of $\mathrm{COD} / \mathrm{BOD}_{5}$ ratio was reported as high (3 \pm 1.89$)$ for WWTP1 (Table 1), the elevation of this ratio indicates an increase of non-biodegradable organic materials in wastwaters causing a disruption of the applied biological process and explains the obtained results regarding the concentration of $\mathrm{BOD}_{5}$ and COD's, both high on the exit of the WWTP1. Similar results were found by other authors $[26,27]$.

\section{Purification Yield}

Regarding the performance of wastewater treatment plants on TSS, COD and $\mathrm{BOD}_{5}$ removal, WWTP2 based on activated sludge ensures high elimination rates of TSS, COD and $\mathrm{BOD}_{5}$ estimated at $98 \pm 0.363$, $91.68 \pm 1.054$ and $91.40 \pm 1.098 \%$ respectively (Table 2) whereas the efficiency of WWTP1 using trickling filter process was in the monitored period very small and did not meet the minimum acceptable treatment efficiency of discharged wastewater according to Rejesk [28]. The average TSS, COD and $\mathrm{BOD}_{5}$ abatement rates registered were $39.86 \pm 15.76, \quad 19.46 \pm 7.926$ and $28.37 \pm 3.194$ respectively (Table 1). The poor performance recorded by WWTP 1 can be attributed to significant factors affecting removal efficiency namely the hydraulic retention time (HRT), the overloading of the plant and the wastewater characteristics [10]. Furthmore, the application of trickling filters process to wastewater treatment has been found profitable when $\mathrm{BOD}_{5}$ of wastewater samples was from 20 to $30 \mathrm{mg} / \mathrm{L}$ [10] , in the case of WWTP 1 , influent $\mathrm{BOD}_{5}$ concentrations were ranged from 40 to $70 \mathrm{mg} / \mathrm{L}$ well above the recommended values.

Compared to other studies conducted in Algeria, Bachi et al. [29] reported that WWTP based on activated sludge process showed satisfactory removal rates of
TSS (95\%), BOD $_{5}(91 \%)$ and COD (89\%) compared to those recorded in plant from the same locality using aerated lagoon process where removal rates were low and levels of the three cited parameters in effluent were above the WHO discharge standards [22]. Similar trends were observed by Elmeddahi et al. [30] with removal efficiencies of $98 \%$ for BOD5, $94 \%$ for COD, and $88 \%$ for TSS for a WWTP located at Chlef (northwest of Algeria) operating with conventional activated sludge process. High values of removal rates were also registered by Hannachi and Gharzouli [31] while studying the efficiency of WWTP in Batna City (Algerian east) who found rates of 91\% (BOD5), 87\% (COD) and 87.6\% (TSS). The observed removal efficiencies for WWTP 2 are consistent with literature data wich reported removal rates mostly greater than $90 \%$ for WWTPs using activated sludge process $[32,33]$.

\section{Application of the EC Process for Removal COD}

\section{Effect of Current Density}

The current density is an essential parameter in the EC process because variation in the $C D$ value highly affects coagulant dosage and bubble production in EC process [34]. To examine the effect of current density on COD removal efficiency, a series of experiments were carried out with the current density ranging from 1.14 to 34.04 and 0.28 to $7.09 \mathrm{~mA} / \mathrm{cm}^{2}$ for WWTP1 and WWTP2, respectively.

As seen clearly in Fig 4 , the removal efficiency of COD increases with increasing current density. This is because of the formation of hydroxyl radical group $\left(\mathrm{Al}^{3+}\right.$ species) at the anode by increasing $\mathrm{CD}$ according to Faraday's law [35]. For optimal current densities values of 29.79 and $4.26 \mathrm{~mA} / \mathrm{cm}^{2}$, COD removal efficiencies were $78 \%$ and $76 \%$ for WWTP1 and WWTP 2, respectively. The high value of $29.79 \mathrm{~mA} / \mathrm{cm}^{2}$ is due to the stronger conductivity of wastewater effluent from 

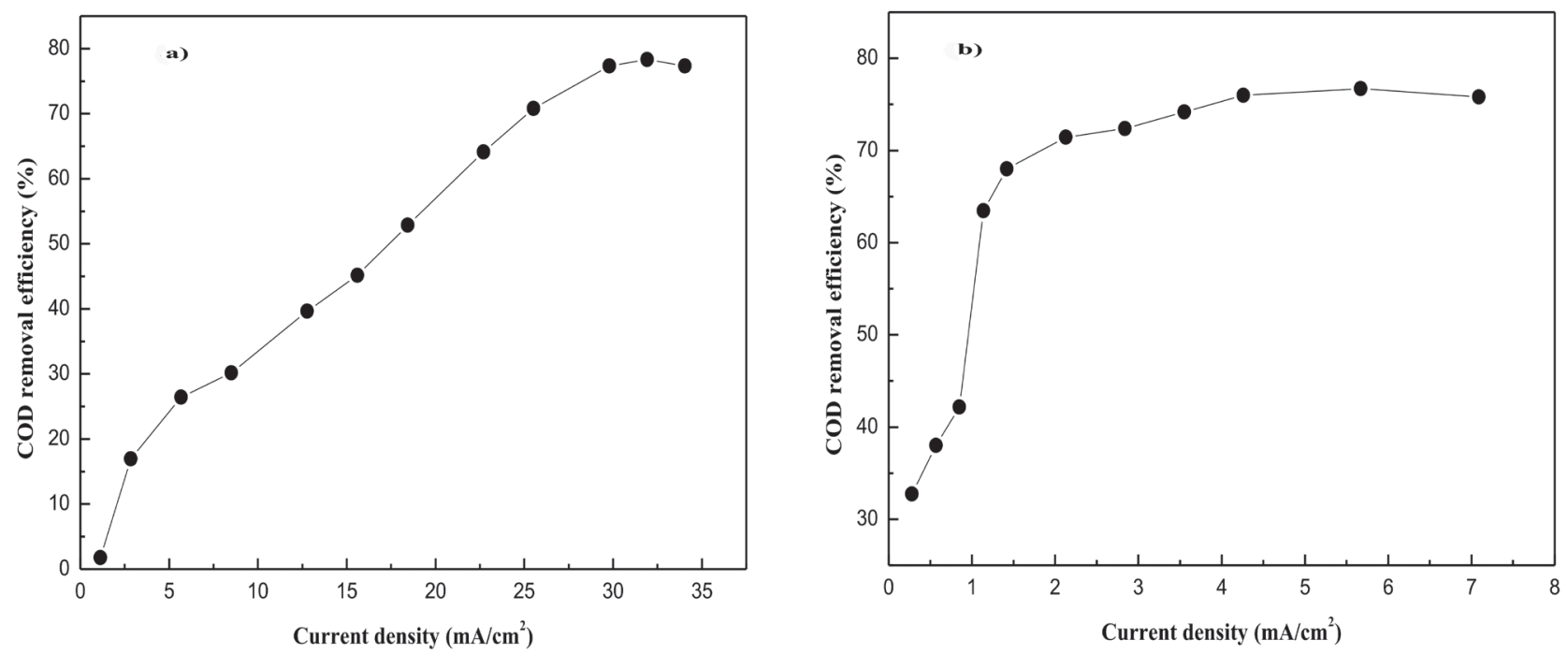

Fig. 4. COD removal efficiency (\%) from waste waters as a function of current density for: a) WWTP 1 at time $=5$ min; $\mathrm{pH}=7.2$; conductivity $=2900 \mu \mathrm{S} / \mathrm{cm}$; stirring $\left.=300 \mathrm{rpm} ; \mathrm{T}=25^{\circ} \mathrm{C} . \mathrm{b}\right) \mathrm{WWTP} 2$ at time $=5 \mathrm{~min} \mathrm{pH}=8.1$ conductivity $=1865 \mu \mathrm{S} / \mathrm{cm}$; stirring $=300 \mathrm{rpm} ; \mathrm{T}=25^{\circ} \mathrm{C}$

the plant 1 [34]. Beyond the above current density values, there was no significant increase in yields for the two stations. Higher current density decreases the COD removal efficiencies. This is due to the increase in the bubble production of $\mathrm{H}_{2(\mathrm{~g})}$ which limits the deposition of organic matter on the cathode, and negatively influences the co-precipitation of the organic compounds with the metal hydroxides in agreement with the works of García-García et al. [36], Nasrullah et al. [37] and Jing et al. [38 ] who confirmed that higher current density resulted in higher COD removal until an optimum value, exceding this value the COD removal rate declines. Similar results have been stated by Tak et al. [39] when investigating the optimization of EC process parameters using statistical methodology, they reported that increasing the current density from 20 to $30 \mathrm{~mA} / \mathrm{cm}^{2}$ led to an increase of COD removal percent from 81 to $92 \%$, beyond $30 \mathrm{~mA} / \mathrm{cm}^{2}$ the removal efficiency decreased. Comparable trend was also observed by Niazmand et al. [40] who noted that by increasing the current density up to $\left(16.5 \mathrm{~mA} / \mathrm{cm}^{2}\right)$, the COD removal efficiency was significantly increased and then decreased.

\section{Effect of Charge Loading}

The charge loading (Eq. 5) is recognized by several authors $[34,41]$ as parameter which influences strongly pollutants removal percentage and the mechanism of the EC process as it controls the coagulant dosage, bubble density and retention time.

The effect of this key parameter was evaluated by varying the treatment time from 0 to $20 \mathrm{~min}$ at the optimum current densities of 29.79 and $4.26 \mathrm{~mA} / \mathrm{cm}^{2}$ for WWTP 1 and WWTP 2 respectively. Fig. 5 showed that for the load values of 26.11 and $3.73 \mathrm{~F} / \mathrm{m}^{3}, 5 \mathrm{~min}$ was sufficient for maximum COD removal efficiencies: $86 \%$ and $75 \%$ for WWTP 1 and WWTP 2 respectively. Beyond these load values, when contact time was greater than $5 \mathrm{~min}$, there was no significant increase in COD removal yield for the two stations indicating that the solid-liquid equilibrium was reached.

The increase of removal efficiency as time could be explained according to Faraday's law (Eq 5) which implies that the amount of metal dissolved ions that are at the origin of coagulants formation (metal hydroxides) increases with time leading to an increase in removal efficiency. Beyond the optimum contact time (5 min), the COD removal efficiency remains constant due probably to the fact that the metal ions and their hydroxides achieved the saturation stage for the flocks formation and sufficient amount of flocs is available for pollutant removal [37, 42]. The large deviation in the load values from WWTP 1 and WWTP 2 is due to the higher difference in the current density.

Our findings are in good concordance with those reported by Tak et al. [39] who confirmed that an increase of electrolysis time from 10 to $20 \mathrm{~min}$ resulted in an increase of COD removal rate from 84 to $88.5 \%$ and optimal efficiency of $93.2 \%$ was achieved during 30 min. Another study [43] showed that the removal efficiency of COD increased from 59.72 to $91.32 \%$ in the interval time of $0.5-5 \mathrm{~min}$ and the optimum electrolysis time was found to be only $1 \mathrm{~min}$. It is important to underline that the electrolysis time obtained in our study (5 $\mathrm{min}$ ) is more economical when it is compared to other studies $[37,38,40]$.

\section{Effect of Initial $p H$}

The initial $\mathrm{pH}$ is considered to be one of the main factors controlling the elimination efficiency 

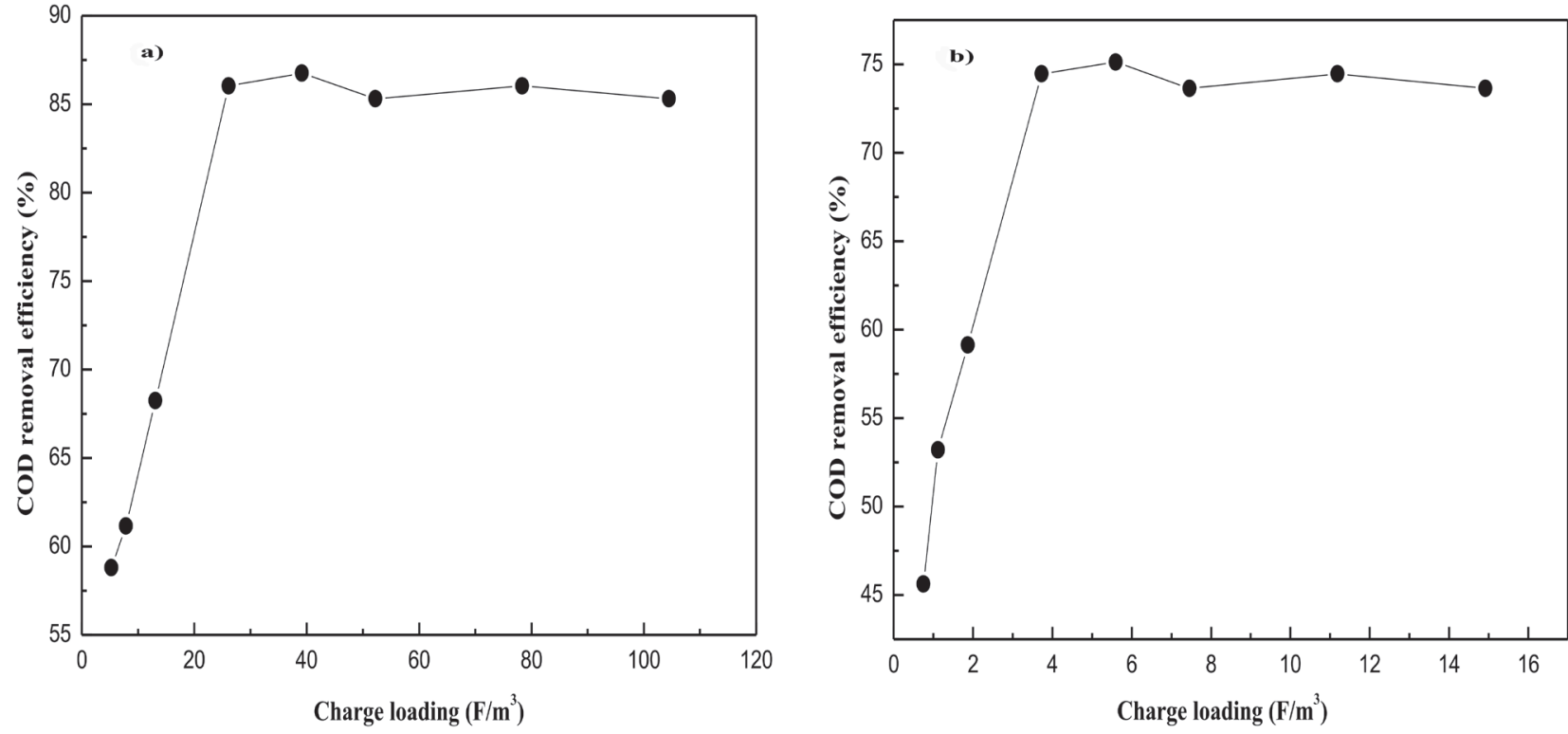

Fig. 5. COD removal efficiency (\%) from waste waters as a function of charge loading for: a) WWTP 1 at current density $=29.79 \mathrm{~mA} / \mathrm{cm}^{2} ; \mathrm{pH}=7.4$; conductivity $=2900 \mu \mathrm{S} / \mathrm{cm}$; stirring $\left.=300 \mathrm{rpm} ; \mathrm{T}=25^{\circ} \mathrm{C} . \mathrm{b}\right)$ WWTP 2 at current density $=4.26 \mathrm{~mA} / \mathrm{cm}^{2}$; $\mathrm{pH}=8.3$; conductivity $=1865 \mu \mathrm{S} / \mathrm{cm}$; stirring $=300 \mathrm{rpm} ; \mathrm{T}=25^{\circ} \mathrm{C}$.

of pollutants by $\mathrm{EC}$ as it determines the speciation of hydroxides in the solution [34, 42, 44]. This means that, depending on the $\mathrm{pH}$, certain species aluminum compounds in equilibrium are predominantly present in the solution. Moreover the $\mathrm{pH}$ of medium changes during the $\mathrm{EC}$ as observed by several investigators $[34,45]$. This change depends on initial $\mathrm{pH}$, electrode material and nature of pollutant removal.

To investigate the effect of $\mathrm{pH}$ on EC performance, a series of experiments were carried out using solutions with an initial $\mathrm{pH}$ varying from 3 to 11 . Fig 6 showed that the highest removal efficiencies of COD were achieved at initial $\mathrm{pH}$ of 3 and were about $79 \%$ and $82 \%$ for WWTP1 and WWTP 2, respectively. Literature data reported that $\mathrm{pH}$ ranging from 4 to 8 generates various species (monomoric and polymeric Aluminum hydroxides) that finally transform into insoluble amorphous $\mathrm{Al}(\mathrm{OH})_{3} \mathrm{~s}$ through complex polymerization [46]. The insoluble $\mathrm{Al}(\mathrm{OH})_{3}$ is the dominant species under these conditions and thus responsible for the
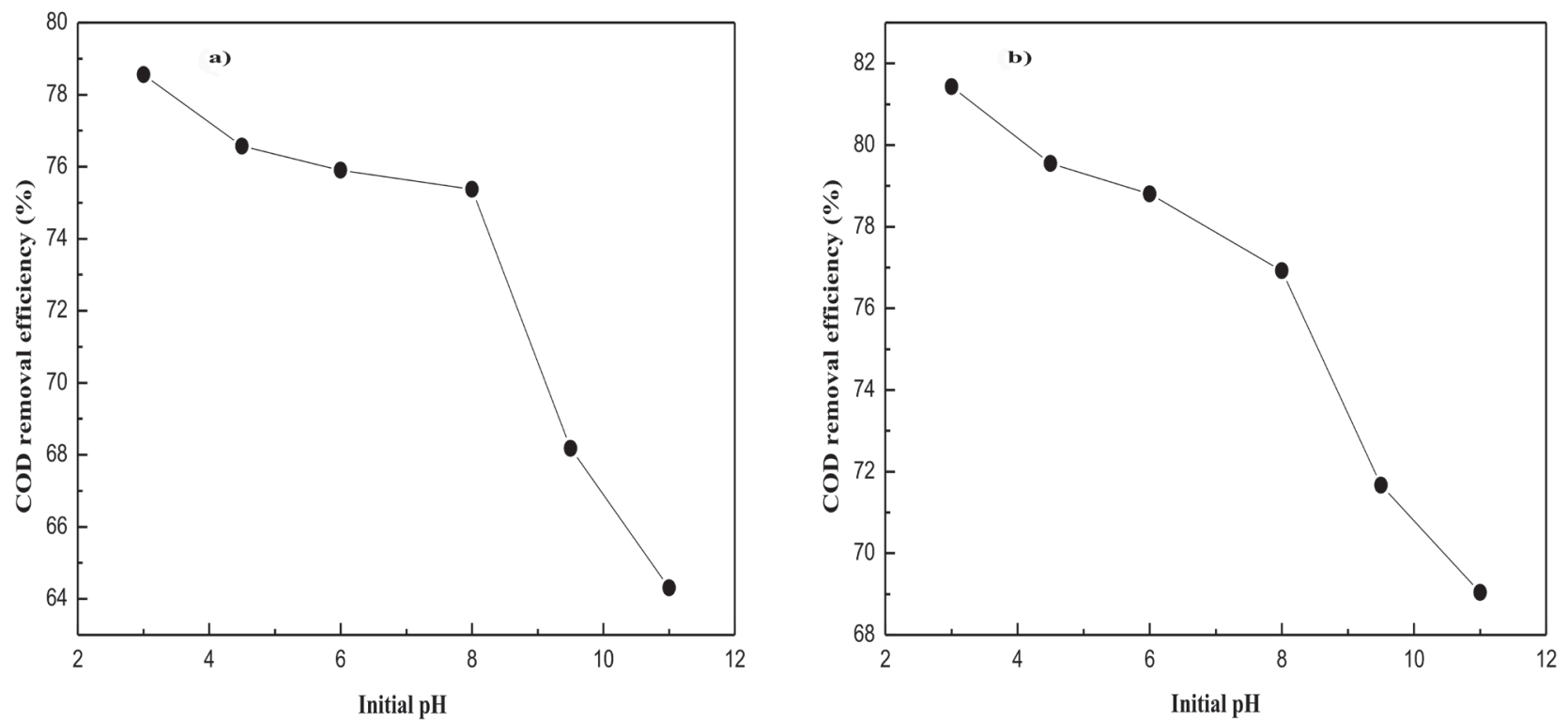

Fig. 6. COD removal efficiency (\%) from wastewaters as a function of initial $\mathrm{pH}$ for: (a) WWTP 1 at current density $=29.79 \mathrm{~mA} / \mathrm{cm}^{2}$; time $=5 \mathrm{~min}$; conductivity $=2900 \mu \mathrm{S} / \mathrm{cm}$; stirring $=300 \mathrm{rpm} ; \mathrm{T}=25^{\circ} \mathrm{C}$. b) WWTP 2 at current density $=4.26 \mathrm{~mA} / \mathrm{cm}^{2} ;$ time $=5 \mathrm{~min}$; conductivity $=1865 \mu \mathrm{S} / \mathrm{cm}$; stirring $=300 \mathrm{rpm} ; \mathrm{T}=25^{\circ} \mathrm{C}$. 
Table 3. Estimation EC cost at the optimum conditions.

\begin{tabular}{|c|c|c|c|}
\hline WWTP & $\begin{array}{c}\text { EEC (KWh/ } \\
\left.\mathrm{m}^{3}\right)\end{array}$ & $\begin{array}{c}\text { EMC } \\
\left(\mathrm{Kg} / \mathrm{m}^{3}\right)\end{array}$ & $\begin{array}{c}\text { Cost } \\
\mathrm{US} \$ / \mathrm{m}^{3}\end{array}$ \\
\hline S1 & 14 & 0.1588 & 0.75 \\
\hline S2 & 0.78 & 0.1888 & 0.18 \\
\hline
\end{tabular}

coagulation. In this case, the highest COD removal rates obtained at initial $\mathrm{pH}$ of 3 confirm that at acidic conditions the $\mathrm{pH}$ of the solutions rise during EC process to reach favorable $\mathrm{pH}$ value for $\mathrm{Al}(\mathrm{OH})_{3}$ precipitation as demonstrated by Vik et al. [45], Duan and Gregory [47] and Mouedhen et al. [48].

Similar results were obtained by other authors who found the electrocoagulation process most effective at low initial $\mathrm{pH}[15,49]$. However, the efficiency of EC decreased with increasing $\mathrm{pH}$ and drops dramatically when the $\mathrm{pH}$ was greater than 8 . These results are explained by the fact that under alkaline conditions, the dominant aluminium form is tetrahydroxyaluminate ion $\mathrm{Al}(\mathrm{OH})_{4}^{-}$(or $\mathrm{Fe}(\mathrm{OH})_{4}^{-}$in case of Iron electrodes) which however dissolves, thus the flocs formation is inhibited leading to a lower process efficiency in consistent with findings of previous studies [39, 50-52].

\section{EC Cost Analysis}

The most important determining factor of the feasibility of any treatment process is its cost. In this study, the operating cost (OC) of EC was calculated as the total of the costs of electrical energy consumption (EEC) and electrode material consumption (EMC) using the following equation [53].

$$
\mathrm{OC}=\mathrm{X} \cdot(\mathrm{EEC})+\mathrm{Y} \cdot(\mathrm{EMC})
$$

...where $\mathrm{X}$ and $\mathrm{Y}$ are the prices of electricity and electrode material, respectively.

The mass of electrode material consumed $(\mathrm{g})$ is estimated from electrodes mass difference before and after electrocoagulation.

According to the Algerian market in September 2020 , the price of the electrode material used was estimated at $0.78 \mathrm{US} \$ / \mathrm{kg} \mathrm{Al}$ and the price of electrical power was evaluated at $0.045 \mathrm{US} \$ / \mathrm{kWh}$.

The operating cost of EC process for removing organic matter from one $\mathrm{m}^{3}$ of wastewater at the optimum conditions was evaluated and was given in Table 3.

Results demonstrate, in first that EC operating costs which correspond to 0.75 and $0.18 \mathrm{US} \$ / \mathrm{m}^{3}$ under optimal conditions $(\mathrm{I}=2.1 \mathrm{~A}$ and $\mathrm{t}=5 \mathrm{~min} ; \mathrm{I}=0.3 \mathrm{~A}$ and $t=5 \mathrm{~min}$ ) for $\mathrm{S} 1$ and $\mathrm{S} 2$ are quite economic and are significantly lower than those reported in several papers [53-57] (Table 4). Secondly, these results are satisfactory because the EC exhibited efficient treatment with a low operating cost particularly for WWTP2, we concluded that EC process, alone or combined, can be considered as solution for real municipal wastewater treatment.

\section{Conclusions}

This study focused on two main parts: the first consisted to assess the performance of two sewage treatment plants using trickling filters (WWTP 1) and activated sludge (WWTP 2) and to ensure compliance with discharge standards and the possibility to reuse treated wastewaters in agriculture. The results showed that the discharge standards are still not met for WWTP 1 , which represents a risk of environmental pollution. The average purification yields in term of $\mathrm{BOD}_{5}$, COD and TSS are: $28.37 \pm 3.194 \%, 19.46 \pm 7.926 \%$ and

Table 4. Comparison between present and previous studies.

\begin{tabular}{|c|c|c|c|c|}
\hline Used electrodes & Optimum conditions & $\begin{array}{c}\text { COD removal efficiency } \\
\%\end{array}$ & $\begin{array}{l}\text { Total cost } \\
\text { US } \$ / \mathrm{m}^{3}\end{array}$ & Reference \\
\hline $\begin{array}{l}\text { Aluminum plate } \\
\text { Iron plate }\end{array}$ & $\begin{aligned} \mathrm{pH}_{\mathrm{i}}=6, \mathrm{t}= & 1 \mathrm{~min}, \mathrm{CD}=0.3226 \mathrm{~mA} / \mathrm{cm}^{2} \\
& {[\mathrm{NaCl}]=1 \mathrm{~g} / \mathrm{L} }\end{aligned}$ & $\begin{array}{l}90.94 \\
91.74\end{array}$ & $\begin{array}{l}0.7062 \\
0.2843\end{array}$ & 43 \\
\hline Aluminum plate & $\begin{array}{l}\mathrm{pHi}=5.31, \mathrm{t}=17.99 \mathrm{~min} \\
\mathrm{CD}=46.83 \mathrm{~mA} / \mathrm{cm}^{2}\end{array}$ & 75.64 & 0.8113 & 53 \\
\hline $\begin{array}{l}\text { Aluminum plate } \\
\text { Iron plate }\end{array}$ & $\begin{array}{l}\text { Flow rate }=0.010 \mathrm{~L} / \mathrm{min} \\
\mathrm{t}=80 \mathrm{~min}, \mathrm{CD}=65 \mathrm{~A} / \mathrm{m}^{2}\end{array}$ & $\begin{array}{c}77.00 \\
85\end{array}$ & $\begin{array}{l}1.851 \\
1.562 \\
\end{array}$ & 54 \\
\hline Aluminium plate & $\begin{aligned} \mathrm{pH}_{\mathrm{i}}= & 7.4, \mathrm{t}=30 \min , \mathrm{CD}=200 \mathrm{~A} / \mathrm{m}^{2} \\
& \text { flocculant dose }=6 \mathrm{~mL} / \mathrm{L}\end{aligned}$ & 85 & $0.7^{*}$ & 56 \\
\hline Aluminum scrap & $\begin{array}{c}\mathrm{pH}_{\mathrm{i}}=7.85, \mathrm{t}=5.84 \mathrm{~min}, \mathrm{C}=1.5 \mathrm{~A} \\
{[\mathrm{NaCl}]=3 \mathrm{mg} / \mathrm{L}}\end{array}$ & 81 & $* *$ & 57 \\
\hline Aluminium plate & $\mathrm{pH}_{\mathrm{i}}=4, \mathrm{t}=60 \mathrm{~min}, \mathrm{CD}=300 \mathrm{~A} / \mathrm{m}^{2}$ & 73.13 & - & 58 \\
\hline Aluminum plate & $\begin{array}{c}(\mathrm{S} 1) \mathrm{pH}_{\mathrm{i}}=3, \mathrm{CD}=29.79 \mathrm{~mA} / \mathrm{cm}^{2}, \mathrm{t}=5 \mathrm{~min} \\
(\mathrm{~S} 2) \mathrm{pH}=3, \mathrm{CD}=4.26 \mathrm{~mA} / \mathrm{cm}^{2}, \mathrm{t}=5 \mathrm{~min}\end{array}$ & $\begin{array}{l}79 \\
82\end{array}$ & $\begin{array}{l}0.75 \\
0.18\end{array}$ & This Study \\
\hline
\end{tabular}

Notes: (S1) WWTP 1, (S2) WWTP 2, * US $\$ / \mathrm{Kg}$ COD removed, ** EC $=3.55 \mathrm{kWh} / \mathrm{m} 3$ 
$39.86 \pm 15.76 \%$ respectively. Therefore, these yields remain very limited and biological treatment alone was not sufficient to provide effective treatment in the plant under examination. The WWTP 2 achieved good yields for the set of studied parameters, they were evaluated to $91.40 \pm 1.098 \%, 91.68 \pm 1.054 \%$ and $98 \pm 0.363 \%$ for $\mathrm{BOD}_{5}, \mathrm{COD}$ and TSS respectively which proved the efficiency of biological treatment based on activated sludge. To improve the functioning of WWTPs we tested, electrocoagulation treatment assays using aluminium electrodes were conducted, this was our principal line of investigation. Experimental findings exhibited high COD removal in comparison to biological treatments particularly for industrial site WWTP that used trickling filters process. The optimum conditions for EC process were identified as initial $\mathrm{pH} 3$, current density $29.79 \mathrm{~mA} / \mathrm{cm}^{2}$, electrolysis time $5 \mathrm{~min}$ and charge loading $26.11 \mathrm{~F} / \mathrm{m}^{3}$. Under these conditions, the removal efficiency of COD was $79 \%$ whereas it was only $19.46 \%$ with trickling filters process and the operating cost was found equal to $0.75 \mathrm{US} \$ / \mathrm{m}^{3}$ which proved that EC is quite economical. These results could be used to improve operation of the WWTP and to plan future modifications for integration electrocoagulation process into the treatment plant.

\section{Acknowledgements}

The authors would like to thank the Directorate General of Scientific Research and Technological Development (DGRSDT) and the Thematic Agency of Research in Biotechnology and Agri-Food Sciences (ATRBSA), Algeria, for their research support.

\section{Conflict of Interest}

The authors declare no conflict of interest

\section{References}

1. SATO T., QADIR M., YAMAMOTO S., ENDO T., ZAHOOR A. Global, regional, and country level need for data on wastewater generation, treatment, and use. A review. Agric. Water. Manag., 130, $1,2013$.

2. Wastewater: the untapped Resource. The United Nations world water development report 2017. Available online: https://reliefweb.int/sites/reliefweb.int/files/ resources/247153e.pdf (accessed on 13/04/2020)

3. SARKER B.C., BATEN M.A., HAQUE M..E., DAS A.K., HOSSAIN A., HASAN M.Z. Heavy metals concentration in textile and garments industries' wastewater of Bhaluka industrial area, Mymensingh, Bangladesh. Curr. World. Environ., 10 (1), 61, 2015.

4. CHABACA N.M., KETTAB A., NAKIB M., KAREF S., BENZIADA S., BENMAMAR S., BOUMALEK W., BOUANANI H., DJILLALI Y. The lagunage for the purification of waste water in the Sahara: an approach integrated into the environmental conditions. Algerian
Journal of Environmental Science and Technology., 3 (2), 419, 2017.

5. HANNACHI A., GHARZOULI R., DJELLOULI TABET

Y. Gestion et valorisation des eaux usées en Algérie (Management and valorisation of wastewater in Algeria). Larhyss Journal, 19, 51, 2014.

6. MURALIKRISHNA I.V., MANICKAM V. Wastewater Treatment Technologies. In Environmental Management, 1st ed.; Elsevier, 249, 2017. Available from: https://www.sciencedirect.com/science/article/pii/ B9780128119891000129?via\%3Dihub

7. PISHGAR R., LEE J., DOMINIC J.A., HOSSEINI S., TAY J.H., CHU A. Augmentation of biogranules for enhanced performance of Full-Scale Lagoon-based municipal wastewater treatment plants. Applied Biochemistry and Biotechnology, 191, 426, 2020.

8. GRANDCLÉMENT C., SEYSSIECQ I., PIRAM A., WONG-WAH-CHUNG P., VANOT G., TILIACOS N., ROCHE N., DOUMENQ P. From the conventional biological wastewater treatment to hybrid processes, the evaluation of organic micropollutant removal: A review. Water Res., 111, $297,2017$.

9. KARNA D., VISVANATHAN C. From Conventional Activated Sludge Process to Membrane-Aerated Biofilm Reactors: Scope, Application, and Challenges. In Water and Wastewater Treatment Technologies. Energy, Environment, and Sustainability., BUI X.T., CHIEMCHAISRI C., FUJIOKA T., VARJANI S. Eds., Springer, Singapore, 237, 2019.

10. ALI I., KHAN Z.M., PENG C., NAZ I., SULTAN M., ALI M., MAHMOUD M.H., NIAZ Y. Identification and Elucidation of the Designing and Operational Issues of Trickling Filter Systems for Wastewater Treatment. Pol. J. Environ. Stud., 26 (6), 2431, 2017.

11. DA SILVA A.J.C., DOS SANTOS E.V., DE OLIVEIRA MORAIS C.C., MARTINEZ-HUITLE C.A., CASTRO S.S.L. Electrochemical treatment of fresh, brine and saline produced water generated by petrochemical industry using $\mathrm{Ti} / \mathrm{IrO}_{2}-\mathrm{Ta}_{2} \mathrm{O}_{5}$ and BDD in flow reactor. Chem. Eng. J., 233, 47, 2013 .

12. PHALAKORNKULE C., SUKKASEM P., MUTCHIMSATTHA C. Hydrogen recovery from the electrocoagulation treatment of dye-containing wastewater. Int. J. Hydrog. Energy. 35, 10934, 2010.

13. SAHU O., MAZUMDAR B., CHAUDHARI P.K. Treatment of wastewater by electrocoagulation: a review. Environmental Science and Pollution Research, 21 (4), 2397, 2014.

14. NAJE A.S., CHELLIAPAN S., ZAKARIA Z., AJEEL M.A., ALABA P.A. A review of electrocoagulation technology for the treatment of textile wastewater. Reviews in Chemical Engineering, 33 (3), 263, 2017.

15. GÖKKUŞ Ö., YILDIZ Y.Ş. Application of electrocoagulation for treatment of medical waste sterilization plant wastewater and optimization of the experimental conditions. Clean. Techn. Environ. Policy., 17 (6), 1717, 2015.

16. EMAMJOMEH M.M., SIVAKUMAR M. Review of pollutants removed by electrocoagulation and electrocoagulation/flotation processes. J. Environ. Manag., 90 (5), 1663, 2009.

17. BAZRAFSHAN E., ALIPOUR M.R., MAHVI A.H. Textile wastewater treatment by application of combined chemical coagulation, electrocoagulation, and adsorption processes. Desalination Water Treat., 57 (20), 9203, 2016. 
18. KLAUSON D., KIVI A., KATTEL E., KLEIN K., VIISIMAA M., BOLOBAJEV J., VELLING S., GOI A., TENNO T., TRAPIDO M. Combined processes for wastewater purification: treatment of a typical landfill leachate with a combination of chemical and biological oxidation processes. J. Chem. Technol. Biotechnol., 90 (8), 1527, 2014.

19. APHA. Standard Methods for the Examination of Water and Wastewater. 22 $2^{\text {nd }}$ edition, APHA-AWWA-WEF, Washington, D.C. 2012: 85, 106, 2012.

20. RODIER J., LEGUBE B., MERLET N., BRUNET R. L'analyse de l'eau (Water analysis), $9^{\text {th }}$ ed.; Dunod: Paris, France, pp. 1600, 2009.

21. Journal Officiel de la République Algériènne N41 2012. ANNEXE : Spécifications des eaux usées épurées utilisées à des fins d'irrigation : Paramètres physico-chimiques (Official Journal of the Algerian Republic N41 2012 Annex: Specifications of purified wastewater used for irrigation : Physico-chemical parameters), 2012.

22. WHO. Guidelines of the safe use of wastewater, excreta and grey water - 3rd ed. Geneva, WHO (third edi.), Geneva, 2006.

23. FAO. Wastewater treatment and use in agriculture. FAO Irrigation and Drainage Paper 47, Rome, FAO, 1992.

24. DINÇER A.R. Increasing BOD5/COD ratio of non-biodegradable compound (reactive black 5) with ozone and catalase enzyme combination. SN Applied Sciences., 2, 736, 2020. https://doi.org/10.1007/s42452-020-2557-y

25. NAGWEKAR P.R. Removal of Organic Matter from Wastewater by Activated Sludge Process-Review. International Journal of Science, Engineering and Technology Research. 3 (5), 1260, 2014.

26. FATHALLAH Z., ELKHARRIM K., FATHALLAH R., HBAIZ E.M., HAMID C., AYYACH A., ELKHADMAOUI A., BELGHYTI D. Etude physicochimique des eaux usees de l'unite industrielle papetiere $(\mathrm{CDM})$ a Sidi Yahia El Gharb (Maroc) (Physico-chemical study of the wastewater of the industrial paper unit (CDM) in Sidi Yahia El Gharb (Morocco). Larhyss Journal, 20, 57, 2014.

27. AL-SULAIMAN A.M., KHUDAIR B.H. Correlation between $\mathrm{BOD}_{5}$ and $\mathrm{COD}$ for al- diwaniyah wastewater treatment plants to obtain the biodigrability indices. Pak. J. Biotechnol., 15 (2), 423, 2018.

28. REJSEK F. Analyse de l'eau : Aspects règlementaires et techniques (Water analysis: Regulatory and technical aspects), ed.; Canopé-CRDP: Bordeaux, France, 360, 2002.

29. BACHI O.E., HALILAT M.T., BISSATI S., MEHANNA S.F. Performance of two free biomass biological wastewater treatment processes (Aerated Lagoon and Activated Sludge) in Ouargla area, Algeria with referring to re-use the treated water in aquaculture. Egyptian Journal of Aquatic Biology and Fisheries., 24 (7), 575, 2020.

30. ELMEDDAHI Y., MAHMOUDI H., ISSAADI A., GOOSEN M.F.A. Analysis of treated wastewater and feasibility for reuse in irrigation: a case study from Chlef, Algeria. Desalination and Water Treatment., 57 (12), 5222, 2015.

31. HANNACHI A., GHARZOULI R. Environmental Context of the Wastewater Treatment Plant (WWTP) of Batna (Algeria). Int J Waste Resour.,7, 274, 2017.

32. NEFAU T., KAROLAK S., CASTILLO L., BOIREAU V., LEVI Y. Presence of illicit drugs and metabolites in influents and effluents of 25 sewage water treatment plants and map of drug consumption in France. Sci Total Environ. 461-462, 712, 2013.

33. FERNÁNDEZ-LÓPEZ C., GUILLÉN-NAVARRO J.M., PADILLA J.J., PARSONS J.R. Comparison of the removal efficiencies of selected pharmaceuticals in wastewater treatment plants in the region of Murcia, Spain. Ecol. Eng., 95, 811, 2016.

34. HAKIZIMANA J.N., GOURICH B., CHAFI M., STIRIBA Y., VIAL C., DROGUI P., NAJA J. Electrocoagulation process in water treatment: A review of electrocoagulation modeling approaches. Desalination, 404, 1, 2017.

35. MOLLAH M.Y.A., MORKOVSKY P., GOMES J.A.G., KESMEZ M., PARGA J., COCKE D.L. Fundamentals, present and future perspectives of electrocoagulation. J Hazard Mater., 114, 199, 2004.

36. GARCÍA-GARCÍA A., MARTÍNEZ-MIRANDA V., MARTIINEZ-CIENFUEGOS I.G., ALMAZÁNSÁNCHEZ P.T., CASTAÑEDA-JUÁREZ M., LINARESHERNÁNDEZ I. Industrial wastewater treatment by electrocoagulation-electrooxidation processes powered by solar cells. Fuel., 149, 46, 2015.

37. NASRULLAH M., ZULARISAM A.W., KRISHNAN S., SAKINAH M., SINGH L., FEN Y.W. High performance electrocoagulation process in treating palm oil mill effluent using high current intensity application. Chinese Journal of Chemical Engineering. 27 (1), 208, 2019.

38. JING G., REN S., GAO Y., SUN W., GAO Z. Electrocoagulation: A Promising Method to Treat and Reuse Mineral Processing Wastewater with High COD. Water, 12 (2), 595, 2020.

39. TAK B.Y., TAK B.S., KIM Y.J., PARK Y.J., YOON Y.H., MIN G.H. Optimization of color and COD removal from livestock wastewater by electrocoagulation process: Application of Box-Behnken design (BBD). Journal of Industrial and Engineering Chemistry, 28, 307, 2015.

40. NIAZMAND R., JAHANI M., SABBAGH F., REZANIA S. Optimization of Electrocoagulation Conditions for the Purification of Table Olive Debittering Wastewater Using Response Surface Methodology. Water, 12 (6), 1687, 2020.

41. KUMAR P.R., CHAUDHARI S., KHILAR K.C., MAHAJAN S.P. Removal of arsenic from water by electrocoagulation. Chemosphere., 55 (9), 1245, 2004.

42. DANESHVAR N., KHATAEE A.R., AMANI GHADIM A.R., RASOULIFARD M.H. Decolorization of C.I. Acid Yellow 23 solution by electrocoagulation process: Investigation of operational parameters and evaluation of specific electrical energy consumption (SEEC). J. Hazard Mater. 148 (3), 566, 2007.

43. TANATTI N.P., ŞENGIL İ.A., ÖZDEMIR A. Optimizing TOC and COD removal for the biodiesel wastewater by electrocoagulation. Applied Water Science, 8 (2), 58, 2018.

44. KOBYA M., DEMIRBAS E., CAN O.T., BAYRAMOGLU M. Treatment of levafix orange textile dye solution by electrocoagulation. J. Hazard. Mater. 132,183, 2006.

45. VIK E.A., CARLSON D.A., EIKUM A.S., GJESSING E.T. Electrocoagulation of potable water. Water Res., 18 (11), $1355,1984$.

46. ISA M.H., EZECHI E.H., AHMED Z., MAGRAM S.F., KUTTY S.R.M . Boron removal by electrocoagulation and recovery. Water Research., 51, 113, 2014.

47. DUAN J., GREGORY J. Coagulation by hydrolysing metal salts. Adv. Colloid Interface Sci., 100-102, 475, 2003.

48. MOUEDHEN G., FEKI M., DE PETRIS WERY M., AYEDI H. F. Behavior of aluminium electrodes in electrocoagulation process. J. Hazard. Mater., 150, 124, 2008. 
49. ATTOUR A., TOUATI M., TLILI M., BEN AMOR M., LAPICQUE F., LECLERC J.P. Influence of operating parameters on phosphate removal from water by electrocoagulation using aluminum electrodes. Sep Purif Technol. 123, 124, 2014.

50. ANANTHA SINGH T.S., RAMESH S.T. An experimental study of CI Reactive Blue 25 removal from aqueous solution by electrocoagulation using Aluminum sacrificial electrode: Kinetics and influence of parameters on electrocoagulation performance. Desalin. Water Treat. 52, 2634, 2014

51. SAFARI S., AZADI AGHDAM M., KARIMINIA H.R. Electrocoagulation for COD and diesel removal from oily wastewater. Int. J. Environ. Sci. Technol. 13, 231, 2016.

52. KONG X., ZHOU Y., XU T., HU B., LEI X., CHEN H., YU G. A novel technique of COD removal from electroplating wastewater by Fenton - alternating current electrocoagulation. Environmental Science and Pollution Research., 27, 15198, 2020.

53. KERMET-SAID H., MOULAI-MOSTEFA N. Optimization of Turbidity and COD Removal from Pharmaceutical Wastewater by Electrocoagulation. Isotherm Modeling and Cost Analysis. Pol. J. Environ. Stud., 24 (3), 1049, 2015.
54. KOBYA M., GENGEC E., DEMIRBAS E. Operating parameters and costs assessments of a real dye house wastewater effluent treated by a continuous electrocoagulation process. Chemical Engineering and Processing: Process Intensification., 101, 87, 2016.

55. FAYAD N., YEHYA T., AUDONNET F., VIAL C. Preliminary purification of volatile fatty acids in a digestate from acidogenic fermentation by electrocoagulation. Separation and Purification Technology, 184, 220, 2017.

56. ELAZZOUZI M., HABOUBI K., ELYOUBI M.S. Electrocoagulation flocculation as a low-cost process for pollutants removal from urban wastewater. Chemical Engineering Research and Design., 117, 614, 2017.

57. ELAZZOUZI M., HABOUBI K., ELYOUBI M.S., EL KASMI A. Development of a novel electrocoagulation anode for real urban wastewater treatment: Experimental and modeling study to optimize operative conditions. Arabian Journal of Chemistry, 14 (1), 102912, 2021.

58. PRAYOCHMEE S., WEERAYUTSIL P., KHUANMAR K. Response Surface Optimization of Electrocoagulation to Treat Real Indigo Dye Wastewater. Pol. J. Environ. Stud., 30 (3), 1, 2021. 